\title{
DNEVI \\ KADROVSKIH DELAVCEV 2000 \\ (v Portorožu od 13, do 15. aprila)
}

L

etošnji Dnevi kadrovskih delavcih, že peti po vrsti v organizaciji Gospodarskega vestnika, so potekali v Kongresnem centru Emona od 13. do 15. aprila pod geslom Pravi ljudje s pravimi sposobnostmi ob pravem času na pravem mestu za pravo ceno. To pravzaprav ne pomeni nič novega. »Kar je novo, je fokus kadrovske funkcije, ki je $\mathrm{v}$ vseh uspešnih podjetjih del managerskega tima in kot taka odgovorna za doseganje poslovnih ciljev. Čeprav se je danes ideja o ravnanju z ljudmi pri delu in o potrebi po preoblikovanju kadrovske službe že dokaj uveljavila, opažamo v Sloveniji precejšnje nasprotje med pričakovanimi, zahtevanimi in dejanskimi spremembami. Dejstvo pa je, da se bodo podjetja prisiljena sprijazniti s povsem novimi razmerami, na to bodo morali biti pripravljeni predvsem ljudje - zaposleni, in

Kadrovska funkcija je vse bolj vpeta v strateško poslovanje podjetja, nosilci nalog kadrovske funkcije pa postajajo tudi managerji in linijski vodje, ki so odgovorni za poslovanje podjetja in uspešnost zaposlenih. Prav tem pa tudi najbolj primanjkuje strokovnih znanj o ravnanju $z$ ljudmi pri delu, torej znanja, ki se praviloma akumulira v kadrovskem sektorju in tako kadrovskim strokovnjakom ponuja novo, ugledno vlogo, vlogo notranjega svetovalca ter vodje sprememb in prav na podlagi te vloge lahko največ pripomorejo $\mathrm{k}$ dobrim odločitvam ter poslovnim rezultatom. da bodo morala podjetja $\mathrm{v}$ času, ko so kapital in informacije dostopni skoraj vsakomur, imeti jasno vizijo prihodnosti, ki jo bodo delila $\mathrm{z}$ vsemi zaposlenimi deratorka letošnjega posveta.

Organizator je tudi opozoril, da tradicionalni funkcijski pogled na organiziranost kadrovske službe ni več primeren.

Podobno kot velja, da je odgovornost za kadre vse bolj v rokah managerjev, tako velja tudi, da se managerji h kadrovskim strokovnjakom zatekajo po strokovno podporo in da so lahko managerji ter kadrovske službe uspešni le, če se med njimi razvije uspešno sodelovanje. Kadrovski strokovnjaki morajo imeti vlogo poslovnega partnerja, kar pomeni, da morajo podjetju pomagati pri oblikovanju in presojanju o primernosti različnih poslovnih strategij ter izbrati tiste strokovne metode, ki bodo podjetju pomagale uresničevati izbrano poslovno strategijo.

V uvodu nam je Brane Gruban v predavanju Enigma človeškega kapitala - strateški premiki pri ravnanju $\mathrm{z}$ ljudmi pri delu predstavil izsledke svoji raziskav in to, kakšen model razvojne vizije ravnanja $z$ ljudmi pri delu sploh potrebujemo in ali se res tako zelo razlikujemo od drugih evropskih držav. Od organizacijske retorike do dejanj je po njegovem mnenju še velik korak, toda silovit razvoj informacijske tehnologije nam ne dopušča veliko časa, temveč zahteva takojšnjo preobrazbo stare miselnosti in hitrejše spreminjanje vedenja posameznikov in organiza- 
cij. Če so ljudje, torej zaposleni, prva skrb kadrovske službe, je njihova skrb tudi vedenje ljudi in pravočasno prilagajanje spremembam. Čeprav je mogoče danes vse razmeroma hitro posnemati, pa so prav ljudje tisti, ki so neposnemljivi, ker imajo $\mathrm{v}$ nasprotju z informacijsko tehnologijo tudi »dušo«, torej svoje sanje, vizije, upanje in potrebe.

Po uvodnem predavanju je potekalo delo $\mathrm{v}$ treh sočasnih sekcijah. V sekciji »Insight« sistem za razvoj medosebnih, timskih in organizacijskih odnosov je Janez Hudovernik poudaril, da - če želimo, da bo naše podjetje uspešno - se moramo nenehno truditi izboljšati sporazumevanje med sodelavci in $\mathrm{s}$ strankami ter poslovnimi partnerji. Ključ do uspešnega sporazumevanja pa je nenehen razvoj osebnih kompetenc. Model »insight« temelji na spoznanjih tipologije osebnosti, ki jo je razvil priznani psiholog Carl Gustav Jung, in omogoča okvir za določanje, merjenje in razvoj osebnih, medosebnih in organizacijskih veščin. Model vključuje tri razsežnosti tri aspekte posameznikove osebnosti: vedenje, naravnanost in vrednote, učenje ter veščine. Tako omogoča spoznati kolektivne zmožnosti in osebnostne potenciale, ki jih ima na voljo organizacija.

V sekciji Izobraževanje ključnih kadrov $\mathbf{v}$ okolju uravnoteženega merjenja uspešnosti - Balance Scorecard je Špela Trefalt poudarila, da smo imeli že večkrat priložnost slišati, da finančna merila ne napovedujejo uspešnosti oziroma neuspešnosti podjetja, saj merijo poslovne učinke za nazaj, ne napovedujejo pa prihodnosti. Idejo uravnoteženega merjenja uspešnosti sta razvila Robert Kaplan in David Norton ter tako postavila nov sistem managementa, ki meri uspešnost na podlagi štirih med seboj povezanih perspektiv: finančne perspektive, perspektive strank, perspektive internih poslovnih procesov in perspektive učenja in rasti. Vsekakor je končni cilj poslovanja podjetja finančne narave in ustvarjanje nove vre- dnosti. Uravnotežen pogled pa zagotavlja večjo verjetnost, da bomo finančne cilje dosegali tudi v prihodnosti. Podjetja morajo gledati na investicije $\mathrm{v}$ izobraževanje tudi $\mathrm{z}$ ekonomskega gledišča in presoditi, ali izobraževanje pomeni »zlata jajca« ali le zapravljanje denarja. Opozorila pa je tudi na to, da slovenska podjetja sicer veliko vlagajo $\mathrm{v}$ izobraževanje $\mathrm{v}$ »dobrih časih«, kadar pa se znajdejo v težavah, najprej zmanjka denarja za izobraževanje, kar je seveda $\mathrm{v}$ popolnem nasprotju $\mathrm{z}$ idejo »Balance Scorecard «.

\section{V sekciji Pomen razvoja no-} tranjih karier nam je Olga Lipič povedala, da postaja kariera za vsakega posameznika čedalje pomembnejša, saj je delo za mnoge ljudi eno izmed osrednjih področij $\mathrm{v}$ življenju. Kariera že dolgo ni več le pojem, rezerviran za elitne poklice in napredovanje po hierarhični lestvici. Pot lahko ubere tudi vstran ali včasih tudi navzdol. Danes, ko organizacije ne vedo več zanesljivo kakšne

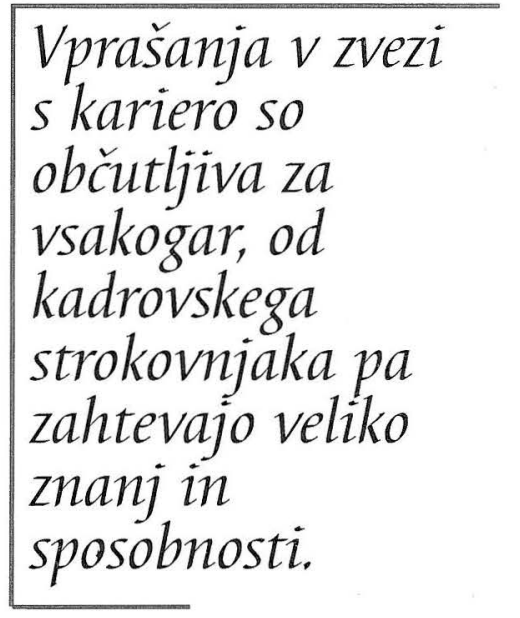
vrste kadrov bodo potrebovale, kariera ne pomeni več le enega poklica ali enega podjetja. Vprašanja v zvezi s kariero so za vsakega posameznika občutljivo področje, lahko pa so tudi vir motivacije ali pa nesporazumov $\mathrm{v}$ organizaciji. Predavateljica je predstavila tudi nekaj modelov kariere, ki bi jih lahko uporabila slovenska podjetja, skupna ugotovitev pa je, da danes vse bolj prevladuje ciklični model kariere, po katerem posameznik vsakih nekaj let zamenja svoj poklic.

Drugi dan posveta sta dr. Stephen Booy in Rainer Matthies predstavila slovenskim kadrovskih delavcem referat Kako lahko še povečamo učinkovitost in produktivnost zaposlenih. Kdor želi uspešno poslovati tudi v naslednjem desetletju, mora kratko malo vedeti, kako pripraviti zaposlene, posameznike ali 
time do tega, da bodo učinkovitejši. Dr. David Kolbe je razvil pojem tako imenovanega managementa na podlagi instinktov: vodstveni in vodilni delavci bi morali razdeliti določene, čeprav spreminjajoče se, naloge pravemu človeku oziroma izbrati takšne naloge, ki ustrezajo človekovemu instinktu. Dr. Kolbe je namreč prepričan, da se je večino spretnosti mogoče naučiti, instinkti pa se ne spreminjajo. Če bomo znali zaposlene naučiti, kako lahko čim bolje izrabijo svoje naravne sposobnosti, bodo ljudje pri delu bolj zadovoljni, denar za izobraževanje bo porabljen učinkoviteje, produktivnost pa se bo povečala tudi za 200 odstotkov. Več kot 500.000 primerov pa dokazuje, da ma-
Gosta iz tujine sta slovenskim predstavila

management na podlagi instinktov. strokovnjakom nagement na podlagi instinkta ni vizija prihodnosti, ampak dokaz, da se vodje te sposobnosti lahko naučijo.

$S$ prepoznavanjem instinktov lahko predvidimo sposobnosti timov, omejimo konflikte in napetosti, poskrbimo, da bomo imeli pravega človeka na pravem delovnem mestu.
V predavanju Mirana Kalčiča Priložnosti in izzivi drugega pokojninskega stebra za oblikovanje kadrovskih strategij smo slišali, da je bil 1. 1. 2000 v Sloveniji uveden tristebrni sistem pokojninskega zavarovanja, ki pomeni zakonski poseg v državno pokojninsko shemo in postopno zmanjševanje nadomestitvene stopnje kot razmerja med povprečno plačo in povprečno pokojnino. Ta poseg v obseg pravic iz državnega zavarovanja je že sam po sebi zahteval uvedbo instrumentov za ohranitev ustrezne ravni socialne varnosti, ki prinašajo določene prednosti delodajalcu in tudi delojemalcu. Prednosti vključevanja v oblike dodatnega pokojninskega zavarovanja in priložnosti, ki se s tem ponujajo kadrovikom za oblikovanje učinkovitih strategij, so predvsem finančne narave in praviloma ve-
$\mathrm{V}$ popoldanskem času pa je potekalo delo $\mathrm{v}$ sekcijah. V sekciji Fleksibilne oblike nagrajevanja - odgovor na zahteve 3. tisočletja nas je Barbara Luckman - Jagodič opozorila, da ključni produktivni dejavnik ni več kapital, ampak ljudje s svojim znanjem in sposobnostmi. Prav zato morajo biti podjetja pri pridobivanju in zadrževanju ključnih kadrov čimbolj inovativna in fleksibilna. V svetu je fiksna plača le manjši del vseh prihodkov. Poleg fiksne plače zaposleni prejemajo še variabilni del plače in kratkoročne in dolgoročne spodbude. Predstavila je tudi izsledke iz raziskave iz leta 1997 o tem, kakšne plačne politike in sisteme nagrajevanja uporabljajo največja slovenska podjetja.

V sekciji Izdelava pokojninskega načrta in izračunavanje je dr. Alenka Žnidaršič Kranjc zelo nazorno predstavila, kaj pomeni dodatno pokojninsko zavarovanje, če ga prikažemo v številkah. Že v plenarnem delu o tretjem stebru pokojninskega zavarovanja smo slišali veliko zanimivosti in možnosti, ki se ponujajo kadrovski službi s sprejetjem novega zakona o invalidskem in pokojninskem zavarovanju. V sekciji Izdelava pokojninskega načrta pa smo imeli priložnost spoznati tudi nekaj praktičnih rešitev. Krajnčeva nas je tudi opozorila, da bo od leta 2020 do 2025 po sedanjih predvidevanjih več zahtevkov za izplačilo pokojnin kot prilivov v pokojninski sklad in da torej lahko pričakujemo težave. Medgeneracijska pogodba pa postaja vse boljj vprašljiva. Na prihodke $\mathrm{v}$ upokojitvenem obdobju je treba misliti torej že danes in izrabiti vse možnosti, ki se nam trenutno ponujajo.

V sekcji Varovanje delavčeve zasebnosti v praksi nas je Gregor Miklič postavil pred dejstvo, da niti zakon niti kolektivne pogodbe posebej ne urejajo delavčeve zasebnosti. Pri obravnavi tega, zelo občutljivega področja se lahko opremo le na mednarodne dokumente in ustavna določila o človekovih pravicah ter svoboščinah. Delavčeva zasebnost in njeno 
varstvo sta $v$ Sloveniji še $v$ povojih. Poleg ustreznih zakonskih določil sta potrebni tudi ustrezna strokovna usposobljenost in zrelost delodajalcev. Trenutno stanje varovanja zasebnosti v Sloveniji ni spodbudno, veliko je kršitev, v obdobju informacijske tehnologije pa te postajajo tudi vse bolj domišljene, od videonadzora na delovnem mestu do preverjanja dela na računalnikih.

Zadnji dan posveta nam je dr. Bogomir Kovač predstavil, kako naj bi deloval kadrovski »outsourcing «, s čimer seveda želimo racionalizirati poslovanje. Govoril je o tem, da mora kadrovska dejavnost izraziti svoje delo tudi $\mathrm{v}$ ekonomskih kazalcih. Prav tako kot druge funkcijske enote je tudi kadrovska funkcija zavezana racionalnemu poslovanju. Nekatera dela lahko laže, hitreje in ceneje opravijo zunanje službe. V globalnem poslovnem okolju je vse več primerov, ko se je pametneje in bolj racionalno odločiti za kadrovski »outsourcing«, kakor pa iskati ustrezne rešitve znotraj podjetja

Janez Balkovec, premoženjski svetovalec, je v predavanju Življenjsko zavarovati zaposlene - da ali ne poudaril, da so tudi zavarovalne pogodbe in police del podjetniškega poslovanja. Verjetno je cilj vsakega podjetja varno in stabilno poslovanje. Podjetja že uporabljajo različne oblike zavarovanja, od zavarovanja elektronskih računalnikov do zavarovanja odgovornosti iz dejavnosti, vse bolj pa se odločajo tudi za osebne oblike zavarovanja, ki so velikokrat povezane tudi $\mathrm{z}$ varčevanjem oziroma izplačilom ob koncu zavarovalne dobe. Pričakovati je, da bo v prihodnje socialna varnost organizirana predvsem na individualni zasnovi in da bodo pri tem različne oblike življenjskega zavarovanja pomenile enega izmed temeljev zagotavljanja denarnih sredstev po upokojitvi. Predavatelj je opozoril tudi na slabe strani takšnih vrst zavarovanja, saj realna vrednost denarja pada, zato je treba dobro premisliti, kdaj se odločiti za življenj-
Organizator je v sklopu posveta Dnevi kadrovskih delaveev 2000 pripravil tudi večerno tribuno s temo Delaholizem, ki jo je vodil Aleks Štakul. Šlo je za prvo strokovno razpravo o pojavu, pred katerim si tudi v Sloveniji ne moremo več zatiskati oči. Konkureněni pritiski in zahteve po vse večjem dobičku nas lahko priženejo v skrajnost - v delo zaradi dela samega. Na Japonskem poročajo o prvem smrtnem primeru zaradi bolezni »karoši oziroma smrti zaradi delovne izěrpanosti. Ugotovitev večerne tribune je, da Slovenci zelo radi delamo in da imajo delodajalci seveda delaholike radi. Toda obstaja nevarnost, da postane delaholizem prevladujoč vzorec organizacijske kulture, vsi pa vemo, da ima človeško telo tudi svoje biološke meje in da s pretiranim delom seveda načenjamo lastno zdravje, kar se navsezadnje pozna tudi v državni blagajni, ki mora več sredstev namenjati za zdravljenje sicer delovno zmožnih državljanov.

sko zavarovanje zaposlenih in na kaj je treba pri tem paziti.

Sklepno razmišljanje letošnjega posveta je predstavila dr. Nada Zupan, ki je udeležencem pojasnila svoje videnje v predavanju Kako lahko še povečamo učinkovitost in ugled kadrovskih služb. Kadrovski managerji in strokovnjaki so pred izzivom, saj morajo za uspešno izvajanje vlog, o katerih je bil govor na posvetu, pridobiti nove vrste znanja. Prav kadrovska služba je tista, ki mora dajati pobude za spremembe. Pri tem pa je predvsem potreben dober zgled, zato mora najprej izvajati spremembe na svojem, torej kadrovskem področju. Raziskave kažejo, da je v slovenskih podjetjih kadrovska funkcija slabo zastopana, da je tudi na tem področju vse očitnejša feminizacija poklica in predvsem premajhna agresivnost po vključevanju kadrovske funkcije v strateško upravljanje podjetja.

Organizator je sklenil posvet $\mathrm{z}$ naslednjimi besedami: »Sporočilo je jasno: kadrovska funkcija ne sme biti le strošek za podjetje, ampak mora s svojimi aktivnostmi dosegati pozitivne spremembe pri zaposlenih in s tem dodajati novo vrednost delovni organizaciji.«

mag. Daniela Brečko 